\title{
ANALISIS STRATEGI BERSAING UKM BATIK SURAKARTA
}

\author{
Isbandriyati Mutmainah \\ Fakultas Ekonomi Universitas Nusa Bangsa Bogor \\ isbandriyati@yahoo.com \\ Irmawati \\ Fakultas Ekonomi dan Bisnis Universitas Muhammadiyah Surakrta, \\ irmawati@ums.ac.id \\ Rumna \\ Fakultas Ekonomi Universitas Nusa Bangsa Bogor \\ szen2104@gmail.com
}

\begin{abstract}
ABSTRAK
Kerajinan batik merupakan bagian dari industri kreatif di Indonesia, namun tidak semua pengusaha batik memiliki strategi bersaing yang tepat, khususnya pengusaha skala UKM. Kualitas strategi bersaing yang rendah merupakan masalah yang perlu diatasi oleh para pelaku UKM batik, sehingga identifikasi faktor-faktor yang mempengaruhi kualitas strategi bersaing penting untuk dilakukan. Studi ini bertujuan untuk menguji pengaruh kualitas aset strategis, adaptabilitas lingkungan, adaptabilitas teknologi informasi, dan orientasi kewirausahaan terhadap kualitas strategi bersaing UKM batik Surakarta. Metode analisis yang digunakan adalah deskriptif dan regresi linier berganda, dengan menggunakan variabel kualitas strategi bersaing sebagai variabel terikat dan variabel aset strategik, adaptabilitas lingkungan, adaptabilitas teknologi informasi dan orientasi kewirausahaan sebagai variabel bebasnya. Analisis deskriptif digunakan untuk mengetahui kualitas strategi bersaing dan variabel-variabel yang mempengaruhinya, sedangkan analisis regresi linier berganda digunakan untuk mengidentifikasi pengaruh variabel-variabel bebas yang dipilih terhadap kualitas strategi bersaing. Dengan menggunakan 90 responden, hasil penelitian menunjukkan bahwa kualitas strategi bersaing UKM batik Surakarta berada pada level berkualitas di mana indikator value memberikan skor yang paling tinggi. Semua variabel bebas yang dipilih memberi pengaruh yang signifikan terhadap kualitas strategi bersaing baik secara bersama-sama maupun parsial dan variabel aset strategik memberikan pengaruh yang paling besar.
\end{abstract}

Kata kunci:

Strategi bersaing, aset strategik, orientasi kewirausahaan, adaptabilitas lingkungan, adaptabilitas teknologi informasi

\begin{abstract}
Batik craft is part of the creative industry in Indonesia, but not all batik entrepreneurs have an appropriate competitive strategy, especially SME scale entrepreneurs. The low quality of competitive strategy is a problem of batik SMEs, so identification of factors influencing the quality of competitive strategy is important to do.This study aims to verify the effect of strategic asset quality, environmental adaptability, information technology adaptability, and entrepreneurial orientation on the quality of the Surakarta batik SME competitive strategy. The analytical method used is descriptive and multiple linear regression, using variable quality competitive strategy as the dependent variable and variable strategic assets, entrepreneurial orientation, environmental adaptability, adaptability of information technology as the independent variable. Descriptive analysis is used to determine the competitive strategic quality and the variables affecting it, while multiple linear regression analysis was used to identify the effect of independent variables on the competitive strategic quality. By using the 90 respondents, the results showed that the competitive strategic quality of SMEs batik in Surakarta was at the qualified level where the "value" indicator provided the highest score. All selected independent variables either in symultaneously or partially gave a significant effect on the competitive strategic quality and the strategic asset variable provided the greatest impact.
\end{abstract}

Keywords: Competitive strategy, strategic assets, entrepreneurial orientation, environmental adaptability, information technology adaptability 


\section{PENDAHULUAN}

Persaingan global yang semakin kompetitif menuntut semua pelaku bisnis memiliki strategi bersaing yang tepat, termasuk pelaku bisnis skala kecil menengah. Salah satu kelemahan yang dimiliki oleh Usaha Kecil Menengah (UKM) adalah kurangnya kemampuan menyusun strategi bersaing yang kompetitif agar mampu bertahan dan memenangkan persaingan baik dengan pesaing domestik maupun pesaing global.

Kontribusi Usaha Kecil dan Menengah (UKM) bagi perekonomian Indonesia tidak perlu dipertanyakan, baik dalam pembentukan PDB, investasi, kemampuan menyerap tenaga kerja, serta total ekspor. Menurut data Kementerian KUKM (2018), UKM merupakan proporsi terbesar dari populasi usaha di Indonesia. Sampai tahun 2017 jumlah UKM mencapai 62,92 juta atau $99,99 \%$ dari total pelaku usaha di Indonesia. Hal ini mengindikasikan bahwa UKM merupakan pilar utama perekonomian Indonesia. Komposisi tersebut terdiri dari usaha mikro sebanyak 62,11 juta unit $(98,70 \%)$, usaha kecil sebanyak 0,76 juta unit $(1,2 \%)$, dan usaha menengah sebanyak 0,059 juta unit $(0,09 \%)$. Jika dilihat dari kontribusinya, sampai tahun 2017 UKM mampu memberikan kontribusi terhadap PDB (harga berlaku) sebesar Rp 7,70 trilyun (60\%), kontribusi terhadap investasi sebesar Rp 2,237 trilyun (58,18\%), kontribusi terhadap penyerapan tenaga kerja sebesar 116,7 juta orang $(97,02 \%)$ dan kontribusi terhadap total ekspor sebesar Rp 298,2 trilyun $(14,17 \%)$.

Di sisi lain, kinerja UKM sendiri masih belum sejalan dengan peran strategis tersebut. Beberapa studi yang telah dilakukan menunjukkan bahwa kinerja UKM masih belum menggembirakan. Studi dari Panggabean (2008) menyatakan bahwa 92\% UMKM belum mampu menjangkau akses permodalan. Demikian juga studi dari Mutmainah (2010) menyatakan bahwa UKM di Kabupaten Bogor rata-rata memiliki kinerja usaha yang berfluktuasi, karena ketidakpastian modal usaha. Sedangkan studi dari Darmansyah dan Soebagyo (2010) menunjukkan kinerja ekspor UKM batik dan garmen batik berfluktuasi, dan ada kecenderungan mulai tahun 2010 mengalami penurunan (Sulistyorini, 2013). Studi dari 
Analisis Strategi Bersaing UKM Batik.... (Isbandriyati Mutmainah, Irmawati \& Rumna)

Paramayoga dan Anshori (2015) juga

menyatakan bahwa terjadi penurunan

produktivitas pengrajin batik Tanjungbumi

Madura. Salah satu variabel yang menyebabkan fluktuasi kinerja UKM adalah kualitas strategi bersaing. Barokah (2011) menyatakan, pelaku UKM belum mampu mengelola strategi bersaingnya dengan baik sehingga perlu ditingkatkan. Dalam era perdagangan bebas, di mana produk-produk pesaing impor membanjiri tanah air, tanpa strategi bersaing yang berkualitas, UKM akan semakin terpuruk (Mutmainah (2010).

Batik merupakan bagian yang tidak terpisahkan dari budaya serta kehidupan sosial masyarakat di Indonesia, bahkan saat ini kerajinan batik sudah menjadi bagian dari industri kreatif di Indonesia (Mutmainah, Irmawati, Rumna, 2016). Sejak diakui UNESCO sebagai warisan budaya Indonesia, hampir seluruh daerah mengembangkan potensi batik yang dimiliki dan potensi ini akan menjadi salah satu kekuatan luar biasa jika digarap dengan serius (Anshori dan Kusrianto, 2011). Sebagai sebuah produk, batik memiliki banyak keunikan yang menjadikan peluang besar produk batik untuk bersaing di pasar internasional. Namun tidak semua pengusaha batik memiliki strategi bersaing yang kompetitif, sehingga model strategi bersaing yang tepat perlu dirancang agar peluang pasar tersebut dapat dioptimalkan. Salah satu cara untuk mampu menghasilkan strategi bersaing yang berkualitas bagi UKM adalah dengan mengidentifikasi faktor-faktor yang menentukan kualitas strategi bersaing. Barney (1991) menyatakan bahwa daya saing ditentukan oleh sumberdaya dan kapabilitas. Dengan menggunakan konsep daya saing dari Barney (1991) tersebut, paper ini bertujuan untuk menguji dan menganalisis pengaruh kualitas aset strategik, adaptabilitas lingkungan, adaptabilitas teknologi informasi dan orientasi kewirausahaan terhadap kualitas strategi bersaing UKM batik di Surakarta.

\section{KAJIAN TEORI DAN PENGEMBANGAN HIPOTESIS}

\section{Aset Strategis}

Barney (1991) menyatakan terdapat syarat untuk menjadi sebuah sumber daya keunggulan bersaing yang berkelanjutan. Aset, nilai dan kecakapan dianggap bernilai ketika aset, nilai dan kecakapan mampu membantu perusahaan dalam memformulasikan dan mengimplementasikan strategi-strategi yang 
memperbaiki efisiensinya atau keefektifannya.

Jika nilai, asset, dan kecakapan tertentu juga dimiliki oleh sejumlah pesaing yang ada sekarang ataupun di masa yang akan datang, maka tidak dapat menjadi sumber daya keunggulan bersaing berkelanjutan. Sedangkan aset nilai dan kecakapan-kecakapan yang berharga dan jarang dimiliki oleh perusahaan lain merupakan suatu sumber daya keunggulan bersaing yang berkelanjutan (Coyne, 1997). Sumber daya yang unik tersebut juga tidak dapat ditiru secara sempurna, dan tidak ada yang secara ekuivalen sebagai pengganti (Barney, 1991). Sumber daya pengganti ini terdiri dua jenis yaitu sumber daya yang sama yang memungkinkan formulasi dan implementasi strategi dan sumber daya pengganti substitusi sebagai pengganti stratejik (Barney, 1991). Coyne (1997) menyatakan bahwa perusahaan yang mempunyai keunggulan bersaing yang berkelanjutan harus mampu menghasilkan produk yang mempunyai perbedaan dengan pesaingnya.

\section{Adaptabilitas Lingkungan}

Lingkungan organisasi merupakan

keseluruhan kondisi dari luar yang berpengaruh terhadap organisasi baik bersumber dari internal maupun external.
Lingkungan internal berkaitan dengan keseluruhan kondisi yang berasal dari perusahaan yang meliputi sumberdaya, kapabilitas, dan kompetensi inti yang dimiliki oleh perusahaan. Sedangkan lingkungan eksternal adalah lingkungan makro dan industri.

Intensitas persaingan dalam suatu industri yang meningkat menyebabkan perusahaan harus memiliki kemampuan adaptasi terhadap lingkungan yang baik. Kemampuan adaptasi terhadap lingkungan merupakan kemampuan untuk merespon secara cepat ketika terjadi perubahan (Gibbons 2003). Brown dan Karagozuglu (1998) dalam Winata dan Sugiarto (2016) menyatakan bahwa strategi perusahaan dalam mengelola lingkungan dapat menciptakan keunggulan bersaing karena tuntutan konsumen yang semakin peka akan pentingnya faktor lingkungan sebagai pendukung kelangsungan hidup manusia. Demikian juga, Chavan (2005) mengemukakan bahwa penerapan manajemen lingkungan yang baik akan membantu perusahaan dalam meraih keunggulan bersaing. Namun demikian, hasil riset menyatakan bahwa dibandingkan dengan perusahaan besar, perusahaan kecil lebih cepat 
menyesuaikan diri dengan perubahan lingkungan, yang akhirnya menjadi salah satu basis keunggulan bersaing perusahaan kecil (Dean J.T, Brown dan Bamford, 1998).

\section{Adaptabilitas Teknologi Informasi}

Lingkungan terbentuk dari dinamika perubahan dan perkembangan, termasuk di dalamnya perubahan teknologi informasi. Teknologi yang berkembang sedemikian cepat, khususnya teknologi informasi, menuntut semua perusahaan untuk mengimbanginya. Untuk dapat bertahan dalam persaingan, perusahaan atau bisnis apapun harus mampu dan fleksibel dalam mengikuti perubahan tersebut. Tingkat kemampuan perusahaan atau bisnis dalam menyesuaikan diri terhadap perubahan teknologi informasi akan berpengaruh terhadap keunggulan bersaing pada akhirnya akan berpengaruh terhadap kinerja perusahaan. Primasari dan Mutmainah (2011) menyatakan bahwa ketidakpastian terhadap perubahan lingkungan, termasuk perubahan teknologi informasi, akan memberikan dampak terhadap penurunan kinerja manajerial perusahaan.

\section{Orientasi Kewirausahaan}

Kewirausahaan mengacu pada penemuan peluang yang ada dan peluang potensial dan kemudian memulai fungsi ekonomi baru dengan membentuk usaha baru (Wennekers et al., 2005). Perilaku wirausaha dapat muncul dalam semua jenis organisasi mulai dari bisnis kecil hingga perusahaan besar, dari perusahaan baru hingga perusahaan yang mapan, dari organisasi nirlaba hingga lembaga pemerintah (Platin dan Ergun, 2017). Semangat kewirausahaan melibatkan kemampuan untuk mengembangkan konsep ide baru dan kemampuan untuk menggunakan sumber daya yang sama secara berbeda untuk menghasilkan output yang heterogen (Bucktowar et al, 2015).

Miller dan Friesen (1982) menyatakan perusahaan yang memiliki jiwa kewirausahaan dicirikan oleh keinginan untuk berinovasi secara reguler dan berani mengambil risiko signifikan dalam strategi kompetitif dan pasar produk mereka. Perusahaan dengan budaya inovatif yang kuat, proaktif terhadap pesaing dan kemauan lebih untuk mengambil risiko, dikatakan terlibat dalam operasi kewirausahaan (Nwachukwu et al. 2017). Dalam perspektif ini, Miller (1983) menyatakan bahwa orientasi kewirausahaan organisasi dapat dilihat sebagai kombinasi dari tiga dimensi yang berbeda: kecenderungan 
inovasi (tendency to innovation), proaktif (proactivity) dan pengambilan risiko (risk taking), dan Lumpkin dan Dess (1996) menambahkan dua dimensi yaitu otonomi (autonomy) dan agresivitas kompetitif (competitive aggressiveness).

Perusahaan dengan budaya inovatif yang kuat, sudut pandang proaktif terhadap pesaing dan kemauan untuk mengambil risiko lebih mungkin terlibat dalam operasi kewirausahaan (Zhang et al, 2012). Inovatif mengacu pada kecenderungan perusahaan untuk terlibat dalam ide-ide baru, eksperimen, proses kreatif yang dapat menghasilkan produk baru, teknologi dan layanan baru (Alarape, 2014). Proaktif mengacu pada bagaimana perusahaan berhubungan dengan peluang pasar dengan mengambil inisiatif di pasar; agresivitas kompetitif mengacu pada bagaimana perusahaan bereaksi terhadap tren dan permintaan kompetitif yang sudah ada di pasar (Lumpkin dan Dess, 2001). Otonomi mengacu pada tindakan independen dari individu atau tim dalam menghasilkan ide atau visi dengan mendorong mereka untuk menerapkan kreativitas dalam rangka menghasilkan sebuah gagasan (Lumpking dan Dess 1996, 2001), pengambilan resiko terkait dengan kemauan perusahaan untuk melibatkan sumber daya pada tingkat yang lebih tinggi dalam proyek-proyek di mana biaya kesalahan bisa sangat tinggi atau hasilnya tidak pasti (Wiklund dan Shepherd 2003; Walter et al. 2006).

\section{Strategi Bersaing}

Setiap perusahaan, baik yang menghasilkan barang maupun jasa, dalam melakukan kegiatan bisnis memerlukan strategi yang mampu menempatkan perusahaan pada posisi yang terbaik, mampu bersaing serta terus berkembang dengan mengoptimalkan semua potensi sumber daya yang dimiliki (Sitepu, 2005). Strategi adalah tentang posisi kompetitif, tentang membedakan perusahaan di mata pelanggan, tentang menambahkan nilai melalui bauran kegiatan yang berbeda dari yang digunakan oleh pesaing (Porter 1985). Strategi bersaing merupakan pencarian posisi bersaing yang tepat dalam industri di mana persaingan terjadi (Porter 1985). Tujuan akhir strategi bersaing adalah untuk mengatasi kekuatan lingkungan demi kepentingan perusahaan (Kuntjoroadi dan Safitri, 2009).

Strategi bersaing merupakan proses mengembangkan keunggulan bersaing dan 
mendapatkan pengembalian rata-rata di atas para pemangku kepentingan atau para pesaing (McGee dan Sammut-Bonnici, 2014). Keunggulan bersaing merupakan keunggulan yang dapat bermakna ganda yaitu di satu sisi sebagai instrumen untuk menghasilkan kinerja dan sisi yang lain sebagai instrumen untuk menetralisir aset dan kompetensi bersaing yang dimiliki oleh pesaing. Strategi bersaing harus diletakkan pada upaya-upaya mencari, mendapatkan, mengembangkan dan mempertahankan sumber daya-sumber daya strategis (Rupidara, 2008).

Keunggulan bersaing dapat ditemukan dari berbagai sumber seperti aset strategik, kemampuan manajemen dalam beradaptasi terhadap perubahan lingkungan dan teknologi informasi maupun jiwa kewirausahaan yang dimiliki pengelola. Porter (1985) menyatakan bahwa sumber keunggulan bersaing dilihat dari kemampuan manajemen dalam menggali kompetensi bidang-bidang fungsional perusahaan seperti kompetensi bidang pemasaran, pengembangan dan desain produk serta produksi. Kompetensi bidang fungsional juga dapat diartikan sebagai pengetahuan nyata dan keterampilan yang secara khusus tercermin dalam keahlian, kemampuan dan kinerja pemasaran, inovasi, penggunaan teknologi dan produksi. Kompetensi yang dimiliki oleh perusahaan hendaknya tidak mudah ditiru oleh pesaing dan menopang tercapainya keunggulan kompetitif yang berkelanjutan (Heene dan Sanches, 1997 dalam Purnama dan Setiawan, 2003). Sedangkan pengembalian di atas rata-rata menggambarkan keuntungan yang lebih unggul dari investasi alternatif dengan profil risiko yang serupa (McGee dan SammutBonnici, 2014).

\section{Hipotesis}

Dalam penelitian ini dikembangkan hipotesis sebagai berikut:

1. Kualitas aset strategis berpengaruh positif terhadap kualitas strategi bersaing

2. Adaptabilitas lingkungan berpengaruh positif terhadap kualitas strategi bersaing

3. Adaptabilitas teknologi informasi berpengaruh positif terhadap kualitas strategi bersaing

4. Orientasi kewirausahaan berpengaruh positif terhadap kualitas strategi bersaing

\section{METODE RISET}


Penelitian ini menggunakan metode deskriptif asosiatif kausal, yang bertujuan untuk menjelaskan masing-masing variabel serta menguji hubungan pengaruh antar varibel yang diteliti sesuai dengan hippotesis yang dibangun. Jenis data yang digunakan dalam penelitian ini berupa data primer dan data sekunder. Data primer diperoleh dengan menyebarkan kuesioner kepada responden terpilih dan indepth interview ke beberapa responden. Sementara data sekunder diperoleh dari studi kepustakaan dengan cara mengumpulkan, mempelajari, dan menelaah buku-buku, majalah, jurnal, publikasi ilmiah dan dokumen yang terkait dengan tujuan penelitian.

\section{Sampel dan Teknik Pengambilan Sampel}

Teknik pengambilan sampel untuk pemilihan sampel yang digunakan adalah kombinasi antara simple cluster sampling dan sensus. Simple cluster sampling untuk menentukan sampel dari dua wilayah yaitu sentra batik Kauman dan sentra batik Laweyan. Pelaku UKM yang digunakan sebagai responden meliputi produsen yang memproduksi bahan atau kain batik sendiri, membuat produk batik sendiri dan menyediakan showroom sendiri; dan yang menyerahkan pembuatan bahan dan motif batik kepada pihak ketiga berdasarkan pesanan. Sedangkan mereka yang hanya mengambil produk jadi dari berbagai pengrajin batik untuk dijual tidak digunakan sebagai responden. Dari 120 pelaku usaha, hanya 90 yang layak digunakan sebagai responden, dengan rincian 35 pelaku UKM batik Kauman dan 57 pelaku UKM batik Laweyan.

\section{Uji Kualitas Data}

Untuk menguji kualitas data digunakan metode reliabilitas dan validitas. Untuk mengestimasi reliabilitas digunakan metode estimasi tunggal dengan menggunakan koefisien alpha Cronbach. Alasan penggunakan koefisien ini adalah dikarenakan sesuai dengan data cross-sectional, aplikatif untuk multi-item scales dan koefisien ini paling banyak digunakan dalam penelitian perilaku konsumen, pemasaran dan persaingan (Cortina, 1993). Besarnya koefisien alpha yang digunakan adalah lebih dari 0,60 (Malhotra, 2009). Sedangkan untuk menguji validitas digunakan pengukuran koefisien korelasi dari rumusan korelasi Product Moment. Menurut Masrun (1979) dalam Sugiyono (2016) teknik korelasi untuk 
menentukan validitas item merupakan teknik yang paling banyak digunakan.

\section{Analisis Deskriptif}

Analisis deskriptif digunakan untuk menganalisis kualitas strategi bersaing UKM batik di Surakarta berdasarkan indikatorindikator yang telah ditetapkan. Jawaban responden mengenai profil ditabulasi dan dianalisis. Jawaban mengenai kualitas bersaing dianalisis dengan Scoring Index $1-5$, dibandingkan dengan standar sehingga dapat dibuat kesimpulan tingkat strategi bersaing yang telah dicapai, apakah sangat berkualitas, berkualitas, cukup berkualitas, kurang berkualitas atau tidak berkualitas.

\section{Regresi Linier Berganda}

Analisis regresi berganda digunakan untuk menguji pengaruh variabel Kualitas aset strategik $\left(\mathrm{X}_{1}\right)$, Adaptabilitas lingkungan $\left(\mathrm{X}_{2}\right)$, Adaptabilitas teknologi informasi $\left(\mathrm{X}_{3}\right)$ dan Orientasi kewirausahaan $\left(\mathrm{X}_{4}\right)$ terhadap variabel Kualitas strategi bersaing UKM batik di Surakarta (Y).

HASIL

PENELITIAN

DAN

PEMBAHASAN

\section{Gambaran Umum Responden}

Profil 90 responden yang berpartisipasi dalam penelitian ini ditunjukkan pada tabel berikut:

Tabel 1. Profil Responden

\begin{tabular}{|c|c|c|}
\hline Profil & Jumlah & Persentase \\
\hline \multicolumn{3}{|l|}{ Wilayah } \\
\hline Kauman & 33 & 36,67 \\
\hline Laweyan & 57 & 63,33 \\
\hline \multicolumn{3}{|l|}{ Gender } \\
\hline - $\quad$ Laki-laki & 43 & 47,78 \\
\hline - $\quad$ Perempuan & 47 & 52,22 \\
\hline \multicolumn{3}{|l|}{ Usia } \\
\hline$-\quad 20-30$ tahun & 15 & 15,67 \\
\hline - $\quad 31-40$ tahun & 29 & 32,22 \\
\hline - $\quad 41-50$ tahun & 26 & 28,89 \\
\hline - $\quad 51-60$ tahun & 18 & 20,00 \\
\hline - $\quad 61-70$ tahun & 2 & 02,22 \\
\hline \multicolumn{3}{|l|}{ Pendidikan } \\
\hline - $\quad$ SLTP & 8 & 08,89 \\
\hline - $\quad$ SLTA & 27 & 30,00 \\
\hline - $\quad$ D3 & 18 & 20,00 \\
\hline$-\quad S 1$ & 34 & 37,78 \\
\hline $\begin{array}{l}-\quad \mathrm{S} 2 \\
\end{array}$ & 3 & 03,33 \\
\hline \multicolumn{3}{|l|}{ Status Perkawinan } \\
\hline - $\quad$ Kawin & 80 & 88,89 \\
\hline - $\quad$ Tidak Kawin & 10 & 11,11 \\
\hline
\end{tabular}

Sebaran responden, 63,33 \% ada di Kampung Batik Laweyan dan 36,67\% ada di sentra batik Kauman. Jumlah responden di Kampung Batik Laweyan lebih banyak karena populasi UKM batik di Kampung Batik Laweyan juga lebih banyak. Sebagian besar pelaku usaha membuat workshop yang menyatu dengan tempat tinggal dan sebagian yang lain memisahkan tempat usaha dengan rumah tinggal. Semua pelaku usaha memiliki merek dagang sendiri-sendiri, dengan nama dan logo yang berbeda satu sama lain. 
Jika dilihat dari jenis kelamin, 52,22\% berjenis kelamin perempuan dan sisanya 48 , $88 \%$ laki-laki. Walaupun tidak ada perbedaan yang mencolok, namun dominasi perempuan dalam kepemilikan usaha ini menunjukkan bahwa UKM batik di Surakarta sudah responsif gender, dalam arti anggapan tradisional pada sebagian masyarakat Surakarta yang menyatakan superioritas lakilaki dalam usaha sudah tidak berlaku di UKM Batik Surakarta. Berdasarkan penelusuran, kepemilikan usaha sebagian besar berdasarkan usaha turun temurun dan hanya sebagian kecil pelaku UKM batik yang tidak memiliki riwayat keluarga sebagai pengusaha batik. Kondisi tersebut ternyata berpengaruh terhadap kepemilikan usaha, dimana perempuan akhirnya diberi kesempatan yang sama dengan laki-laki dalam menjalankan usahanya.

Jika dilihat dari usia pemilik usaha, 97,88\% pelaku usaha merupakan tenaga kerja usia produktif dan hanya 2,22 \% yang berusia di atas 60 tahun. Banyaknya pelaku usia produktif ini memberikan gambaran bahwa UKM batik Surakarta memiliki kontribusi yang besar terhadap pemerintah dalam hal upaya mengurangi tingkat pengangguran.
Banyaknya pelaku usaha yang berusia produktif juga memberi kontribusi terhadap peningkatan kesejahteraan keluarga dengan semakin berkurangnya angka ketergantungan.

Dari sisi tingkat pendidikan yang dicapai, mayoritas pelaku usaha berpendidikan perguruan tinggi dan hanya $8,89 \%$ pelaku usaha yang berpendidikan terakhir SLTP. Ini memberi gambaran bahwa UKM tidak selalu identik dengan usaha yang dilakukan oleh orang yang berpendikan rendah. Dari jawaban responden dapat dijelaskan bahwa menjadi pelaku usaha adalah pilihan, bukan karena ketidakmampuan mereka mengakses lapangan kerja. Dan bagi sebagian besar responden, tingkat pendidikan sangat penting bagi perkembangan usaha khususnya berkaitan dengan analisis usaha dan kemampuan mengatasi masalah.

Karakteristis Usaha pada UKM Batik Surakarta

$$
\text { Gambaran karakteristik responden }
$$
secara rinci dapat di lihat pada tabel 2. 
Tabel 2. Karakteristik Usaha UKM Batik Surakarta

\begin{tabular}{|c|c|c|}
\hline Karakteristik & $\underset{\text { humla }}{\mathrm{J}}$ & $\begin{array}{c}\text { Persentas } \\
\text { e }\end{array}$ \\
\hline \multicolumn{3}{|l|}{ Lama Usaha } \\
\hline $\begin{array}{lll} & \text { Antara } & 1\end{array}$ & 27 & 30,00 \\
\hline sampai 5 tahun & 29 & 32,22 \\
\hline$->5-10$ tahun & 7 & 7,78 \\
\hline$->10-15$ & 27 & 30,00 \\
\hline $\begin{array}{l}\text { tahun } \\
\text { - } \quad \begin{array}{l}\text { Lebih dari } 15 \\
\text { tahun }\end{array}\end{array}$ & & \\
\hline \multicolumn{3}{|l|}{$\begin{array}{l}\text { Jenis Produk yang } \\
\text { Dihasilkan }\end{array}$} \\
\hline \multirow{7}{*}{ 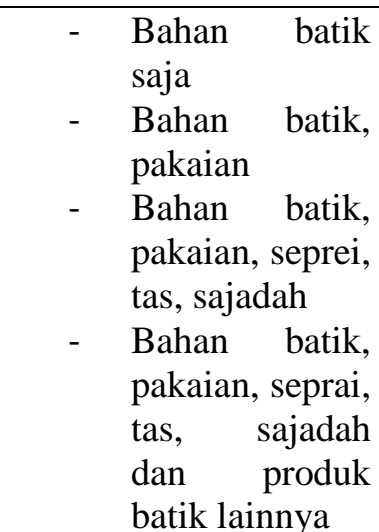 } & 17 & 18,89 \\
\hline & 32 & 35,56 \\
\hline & 1 & 1,11 \\
\hline & 40 & 44,44 \\
\hline & & \\
\hline & & \\
\hline & & \\
\hline \multicolumn{3}{|l|}{ Bentuk Perusahaan } \\
\hline - $\quad$ Belum & 15 & 16,67 \\
\hline berbadan & 66 & 73,33 \\
\hline hukum & 7 & 7,78 \\
\hline - Perusahaan & 1 & 1,11 \\
\hline Perseorangan & 1 & 1,11 \\
\hline$-\quad \mathrm{CV}$ & & \\
\hline - $\quad$ Firma & & \\
\hline$-\quad \mathrm{PT}$ & & \\
\hline \multicolumn{3}{|l|}{ Pasar Sasaran } \\
\hline - $\quad$ Kota Surakarta & 10 & 11,11 \\
\hline - Karesidenan & 2 & 2,22 \\
\hline Surakarta & 8 & 8,89 \\
\hline - Jawa Tengah & 17 & 18,89 \\
\hline - Pulau Jawa & 46 & 51,11 \\
\hline - Seluruh & 7 & 7,78 \\
\hline Indonesia & & \\
\hline $\begin{array}{l}\text { Dalam \& Luar } \\
\text { Negeri }\end{array}$ & & \\
\hline \multicolumn{3}{|l|}{ Jumlah Karyawan } \\
\hline - $\quad 1-10$ orang & 64 & 71,11 \\
\hline - $\quad 11-20$ orang & 15 & 16,67 \\
\hline - $\quad 21-30$ orang & 4 & 4,44 \\
\hline - $\quad 31-40$ orang & 1 & 1,11 \\
\hline
\end{tabular}

\begin{tabular}{|r|r|r|}
\hline$-\quad>40$ orang & 6 & 6,67 \\
\hline \multicolumn{3}{|c|}{ Karakteritik usaha responden dilihat } \\
\hline
\end{tabular}

dari lama usaha, jenis produk yang dihasilkan, bentuk perusahaan, pasar sasaran dan jumlah karyawan. Jika dilihat dari lama usaha, sebagian besar responden $(32,22 \%)$ telah menjalankan usahanya selama 5 sampai 10 tahun. Lama usaha kurang dari 5 tahun dan lebih dari 15 tahun masing-masing 30\%. Mayoritas responden menghasilkan semua produk batik $(44,44 \%)$, baik itu bahan batik, pakaian pria wanita, tas, sajadah dan produkproduk batik lainnya, dan mayoritas menjual produknya ke seluruh wilayah Indonesia dan ada sekitar $7,78 \%$ yang memasarkan produknya baik ke dalam negeri maupun luar negeri. Berdasarkan jawaban responden, mereka sebagian sudah memanfaatkan media sosial dalam memasarkan produknya dan memperluas pasarnya. Karena masih skala UKM, mayoritas responden masih merupakan perusahaan perseorangan $(73,33 \%)$ dan hanya $16,67 \%$ yang belum berbadan hukum

Seperti halnya UKM-UKM lainnya, mayoritas responden memiliki karyawan tidak lebih dari 10 orang dan sebagian besar mereka merupakan karyawan toko. Terdapat $6,67 \%$ yang memiliki karyawan lebih dari 40 orang, 
yang meliputi karyawan bagian produksi bahan, penjahit sampai ke pelayan toko. Dapat disimpukan bahwa pelaku UKM batik Surakarta sebagian besar merupak kelompok usaha mikro kecil dan hanya sebagian kecil yang merupakan kelompok usaha menengah.

\section{Kualitas Strategi Bersaing UKM Batik}

\section{Surakarta}

Kualitas Strategi Bersaing dalam penelitian ini dianalisis dengan melihat ratarata skor yang dicapai dari masing-masing indikator dan persentase sebaran jawaban resonden. Hasil capaian rata-rata skor dapat dilihat pada tabel 3 .

Dalam penelitian ini, kualitas strategi bersaing didefinisikan sebagai kualitas strategi yang digunakan perusahaan dalam menghadapi pesaing dengan mempertimbangkan dan memanfaatkan semua sumber daya strategik yang dimiliki. Variabel kualitas strategi bersaing dicerminkan dengan empat indikator yaitu kemampuan sumber daya untuk dapat digunakan untuk memanfaatkan kondisi eksternal dan menetralisir faktor-faktor eksternal yang tidak menguntungkan (value), tidak ada pesaing yang memiliki sumber daya yang sama (rareness), unik (hard to imitate) dan memiliki

kemampuan dalam memanfaatkan sumber

Tabel 3. Skor Indikator Variabel Kualitas Strategi Bersaing

\begin{tabular}{|l|c|}
\hline \multicolumn{1}{|c|}{ Indikator } & $\begin{array}{c}\text { Rata- } \\
\text { rata } \\
\text { Skor }\end{array}$ \\
\hline 1. $\quad$ Bernilai (value) & 4,00 \\
\hline 2. Langka (rareness) & 3,83 \\
\hline 3. Sukar ditiru (hard to imitate) & 3,61 \\
\hline 4. $\quad \begin{array}{l}\text { Kemampuan dalam } \\
\text { memanfaatkan (ability to exploit) }\end{array}$ & 3,13 \\
\hline $\begin{array}{l}\text { Rata-rata skor variable kualitas } \\
\text { bersaing }\end{array}$ & $\mathbf{3 , 6 4}$ \\
\hline
\end{tabular}

Sumber: Data Responden (2015)

Tabel 4. Sebaran Jawaban Responden

\begin{tabular}{|c|c|c|c|c|c|}
\hline & 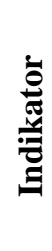 & 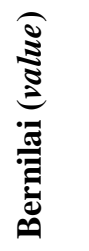 & 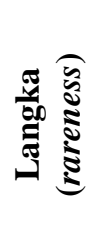 & 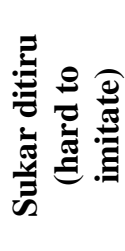 & 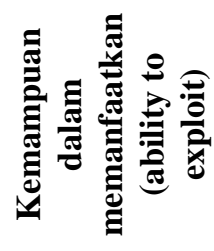 \\
\hline \multirow{10}{*}{$\Xi$} & 1 & 0 & 0 & 2 & 3 \\
\hline & $\%$ & 0 & 0,00 & 2,22 & 3,33 \\
\hline & 2 & 1 & 3 & 11 & 21 \\
\hline & $\%$ & 1,11 & 3,33 & 12,22 & 23,33 \\
\hline & 3 & 20 & 20 & 28 & 34 \\
\hline & $\%$ & 22,22 & 26,67 & 31,11 & 37,78 \\
\hline & 4 & 48 & 48 & 28 & 25 \\
\hline & $\%$ & 53,33 & 53,33 & 31,11 & 27,78 \\
\hline & 5 & 21 & 15 & 21 & 7 \\
\hline & $\%$ & 23,33 & 16,67 & 23,33 & 7,78 \\
\hline
\end{tabular}

Sumber: Data Responden (2015)

daya tersebut (ability to exploit) (Pearce dan Robinson dalam Kuncoro, 2012). Secara keseluruhan rata-rata skor yang dicapai variabel kualitas strategi bersaing adalah 3,64 atau pada posisi berkualitas, dengan skor paling tinggi adalah bernilai dengan skor 4,00 dan skor paling rendah adalah kemampuan dalam memanfaatkan, yaitu sebesar 3,13. 
Dengan demikian, rata-rata produk yang dihasilkan oleh para pelaku UKM batik Surakarta, kecuali untuk indikator kemampuan untuk memanfaatkannya sudah pada level berkualitas sehingga dianggap mampu bersaing dengan produk batik sejenis dari daerah lain maupun dari luar negeri. Namun demikian, tetap perlu upaya untuk meningkatkan, atau paling tidak mempertahankan kualitas strategi bersaingnya, khususnya pada indikator kemampuan untuk memanfaatkannya. Perlu inovasi dan kreativitas untuk menghasilkan produk-produk batik yang lebih marketable.

Jika dilihat dari skor indikator bernilai (value), diperoleh skor 4,00 atau pada level berkualitas. Hal ini dapat diartikan bahwa responden setuju dan menganggap bahwa produk batik yang dihasilkan bernilai dan mampu bersaing di pasar. Bernilai di sini dapat diartikan bahwa produk batik mampu memberikan nilai manfaat baik bagi produsen maupun penggunanya. Hal ini juga didukung oleh jawaban responden di mana 55,33\% menyatakan bahwa produk yang dihasilkan bernilai. Didukung dengan ditetapkannya batik sebagai salah satu warisan dunia menjadikan masyarakat baik dari dalam dan luar negeri menggunakan batik dalam kegiatan seharihari.

Jika dilihat dari skor indikator kelangkaan, diperoleh skor 3,83 yang berada pada level langka. Dari jawaban responden dapat dijelaskan bahwa walaupun jenis produk batik adalah unik, bahan baku juga unik sehingga hanya sedikit pengusaha yang mampu memilikinya. Penyediaan bahan baku pada umumnya dikendalikan sendiri, atau berdasarkan pesanan sehingga kecil kemungkinan adanya duplikasi bahan dari produsen lain. Berdasarkan sebaran jawaban responden diperoleh data bahwa 55,33\% responden mengatakan mereka menguasai bahan baku batik yang dihasilkan.

Jika dilihat dari skor indikator tingkat kesulitan untuk ditiru diperoleh skor 3,61 yang berada pada level sulit. Hal ini dapat diartikan bahwa jenis, dan motif batik yang dihasilkan UKM batik Surakarta unik dan memiliki ciri khas tertentu baik mengikuti pakem batik khas Solo maupun ciri khas dari masing-masing produsen. Kondisi ini didukung dengan sebaran jawaban responden sekitar 62,22 persen menyatakan cukup sulit dan sulit untuk ditiru. Motif batik merupakan motif yang sangat tergantung dari kreativitas produsen. 
Ada yang mengikuti pakem-pakem yang ada dan ada yang membuat motif bebas. Namun dengan seiring semakin meluasnya pengguna batik mendorong pelaku usaha mengikuti trend-trend mode yang sedang berlangsung, sehingga dampaknya tingkat kemiripan produk satu produsen dengan produsen lain cukup besar. Namun perlu diupayakan pemahaman tentang pentingnya hak cipta untuk produk batik untuk menghindari cara-cara legal yang dilakukan pesaing seperti meniru atau mencuri ide pengusaha.

Jika dilihat dari skor indikator tingkat kemampuan dalam memanfaatkan, diperoleh skor 3,13 atau pada level cukup mampu. Artinya masih terdapat keterbatasan skill dan sumber daya kompelemen lainnya menyebabkan pelaku usaha belum mampu mengoptimalkan sumber daya yang dimiliki. Hal ini juga didukung oleh jawaban responden yang menyatakan $37,78 \%$ menyatakan bahwa pelaku UKM batik Surakarta cukup mampu memanfaatkan sumberdaya yang mereka miliki untuk bersaing dengan kompetitornya.

Pengaruh Aset Strategis, Adaptabilitas Lingkungan, Adaptabilitas Teknologi Informasi, dan Orientasi Kewirausahaan terhadap Kualitas Strategi Bersaing
Hasil pengujian realibilitas dan validitas data menunjukkan tingkat kekonsistenan dan keakurasian yang cukup baik. Pada uji reliabilitas, konsistensi internal koefisien Cronbach's Alpha menunjukkan tidak ada koefisien yang kurang dari nilai batas minimal 0,60 (Sugiyono, 2016) Sedangkan pada pengujian validitas dengan uji homogenitas data dan uji korelasional antara skor masingmasing butir dengan skor total (Pearson Correlation) menunjukkan korelasi yang positif dan tingkat signifikan pada level 0,01. Dari hasil tersebut dapat diartikan bahwa pertanyaan-pertanyaan yang mengukur variabel kualitas aset strategis, adaptabilitas lingkungan, adaptabiltas teknologi informasi, orientasi kewirausahaan dan kualitas bersaing dapat dipergunakan dan valid. Hasil uji reliabilitas dan validitas disajikan pada tabel 5 .

\section{Analisis Regresi Berganda}

Uji Pelanggaran Asumsi Klasik

\section{1) Normalitas}

Uji normalitas bertujuan untuk menguji apakah dalam model regresi, variabel pengganggu atau residual memiliki distribusi normal. Salah satu cara untuk mengetahui residual suatu model berdistribusi normal atau tidak dengan 
Analisis Strategi Bersaing UKM Batik.... (Isbandriyati Mutmainah, Irmawati \& Rumna)

menggunakan Histogram dan Normal

probability plot dari residual tersebut.

Tabel 5. Hasil Uji Reliabilitas Instrumen

\begin{tabular}{|c|l|c|c|}
\hline $\begin{array}{c}\text { No } \\
\cdot\end{array}$ & \multicolumn{1}{|c|}{ Variabel } & $\begin{array}{l}\text { Nilai } \\
\text { Cronbac } \\
\text { h Alpha }\end{array}$ & $\begin{array}{c}\text { Keteranga } \\
\mathbf{n}\end{array}$ \\
\hline 1 & $\begin{array}{l}\text { Kualitas Aset } \\
\text { Strategis }\end{array}$ & 0,805 & Reliabel \\
\hline 2 & $\begin{array}{l}\text { Adaptabiltas } \\
\text { Lingkungan }\end{array}$ & 0,728 & Reliabel \\
\hline 3 & $\begin{array}{l}\text { Adaptabilitas } \\
\text { Teknologi } \\
\text { Informasi }\end{array}$ & 0,865 & Reliabel \\
\hline 4 & $\begin{array}{l}\text { Orientasi } \\
\text { Kewirausahaa } \\
\text { n }\end{array}$ & 0,896 & Reliabel \\
\hline 5 & $\begin{array}{l}\text { Kualitas } \\
\text { Bersaing }\end{array}$ & 0,612 & Reliabel \\
\hline
\end{tabular}

Sumber: data primer diolah 2015

Tabel 6. Hasil Uji Validitas Instrumen

\begin{tabular}{|c|c|c|c|c|c|}
\hline No & Variabel & 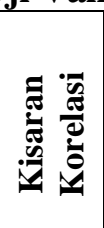 & ब & 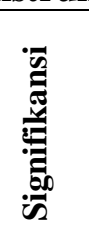 & 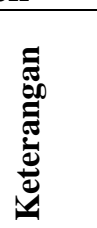 \\
\hline 1 & $\begin{array}{l}\text { Kualitas Aset } \\
\text { Strategis }\end{array}$ & $\begin{array}{c}0,31 \\
4- \\
0,57 \\
3\end{array}$ & $\begin{array}{c}0,27 \\
0\end{array}$ & $\begin{array}{c}0,00 \\
1\end{array}$ & Valid \\
\hline 2 & $\begin{array}{l}\text { Adaptabiltas } \\
\text { Lingkungan }\end{array}$ & $\begin{array}{c}0,32 \\
4- \\
0,54 \\
9\end{array}$ & $\begin{array}{c}0,27 \\
0\end{array}$ & $\begin{array}{c}0,00 \\
1\end{array}$ & Valid \\
\hline 3 & $\begin{array}{l}\text { Adaptabilitas } \\
\text { Teknologi } \\
\text { Informasi }\end{array}$ & $\begin{array}{c}0,51 \\
1- \\
0,80 \\
3\end{array}$ & $\begin{array}{c}0,27 \\
0\end{array}$ & $\begin{array}{c}0,00 \\
1\end{array}$ & Valid \\
\hline 4 & $\begin{array}{l}\text { Orientasi } \\
\text { Kewirausahaan }\end{array}$ & $\begin{array}{c}0,38 \\
6- \\
0,72 \\
6\end{array}$ & $\begin{array}{c}0,27 \\
0\end{array}$ & $\begin{array}{c}0,00 \\
1\end{array}$ & Valid \\
\hline 5 & $\begin{array}{l}\text { Kualitas } \\
\text { Bersaing }\end{array}$ & $\begin{array}{c}0,33 \\
9- \\
0,50 \\
9 \\
\end{array}$ & $\begin{array}{c}0,27 \\
0\end{array}$ & $\begin{array}{c}0,00 \\
1\end{array}$ & Valid \\
\hline
\end{tabular}

Sumber: data primer diolah 2015

Dari histogram persamaan regresi yang

dibangun dapat dilihat bahwa data

distribusi residu menunjukkan distribusi normal. Juga pada normal probability

plot dapat dilihat sebaran error masih

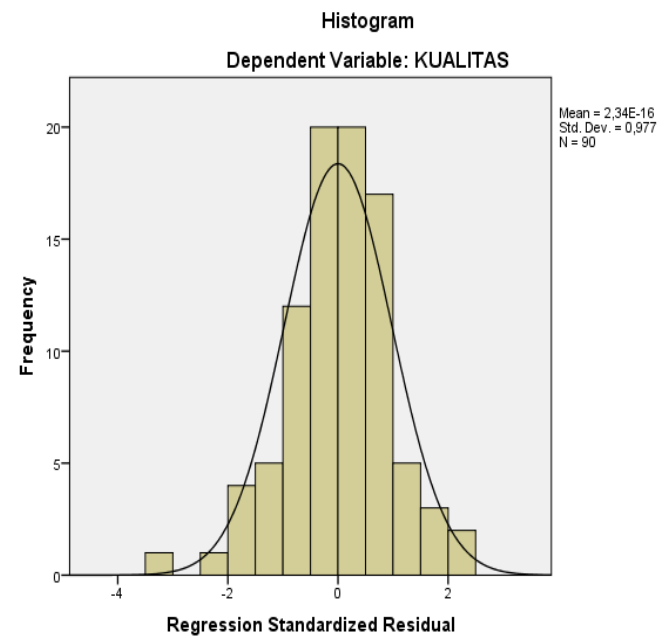

Gambar 1. Histogram dan Probability Plot

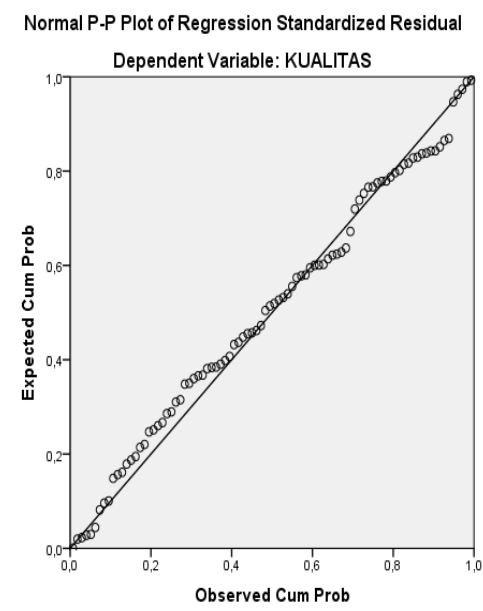

berada pada sekitar garis lurus. Hal ini menunjukkan model regresi yang bangun memenuhi asumsi normalitas atau residu dari model tersebut berdistribusi normal.

\section{2) Multikolinieritas}

Multikolinieritas adalah kondisi yang menunjukkan adanya hubungan linear yang signifikan antara beberapa atau 
semua variabel independen dalam model

regresi. Deteksi ada tidaknya masalah multikolinieritas dalam model penelitian ini, dilihat dari besaran condition index dari proses Collinearity Index.

Dengan melihat nilai Condition Index pada Collinearity Diagnostic dapat dijelaskan bahwa pada persamaan regresi yang dibangun variabel kualitas aset strategis, adaptabilitas lingkungan, adaptabilitas teknologi informasi, dan orientasi kewirausahaan tidak mengalami masalah multikolinier. Ini ditunjukkan dengan nilai Condition Index yang lebih kecil dari 30 untuk ke empat variabel tersebut.

\section{3) Heteroskedastistas}

Asumsi yang dipakai dalam penerapan model regresi linear adalah varians dari setiap gangguan adalah konstan. Heteroskedastisitas adalah keadaan di mana asumsi di atas tidak tercapai. Dampak adanya heteroskedastisitas adalah tidak efisiennya proses estimasi, sementara hasil estimasinya sendiri tetap konsisten dan tidak bias. Dengan adanya masalah heteroskedastisitas akan mengakibatkan hasil uji $\mathrm{t}$ dan $\mathrm{F}$ dapat menjadi tidak berguna (misleading).

Tabel 7. Tabel Ringkasan Collinearity Diagnostic

\begin{tabular}{|l|c|}
\hline \multicolumn{1}{|c|}{ Variabel } & $\begin{array}{c}\text { Condition } \\
\text { Index } \\
\text { Persamaan } \\
\mathbf{2}\end{array}$ \\
\hline Kualitas Aset Strategis & 1,000 \\
\hline Adaptabiltas Lingkungan & 10,940 \\
\hline $\begin{array}{l}\text { Adaptabilitas Teknologi } \\
\text { Informasi }\end{array}$ & 14,859 \\
\hline Orientasi Kewirausahaan & 15,128 \\
\hline
\end{tabular}

Uji heteroskedastisitas dilakukan untuk menguji apakah dalam model regresi terjadi ketidaksamaan varian dari residual satu pengamatan ke pengamatan yang lain. Jika varian dari residual pengamatan yang lain tetap, maka disebut homoskedastisitas. Sedangkan jika varian residual berubah seiring dengan perubahan pengamatan, maka dikatakan persamaan tersebut memiliki masalah heteroskedastisitas. Pada penelitian ini, ada atau tidaknya masalah heteroskedastisitas dapat dilihat dengan plot khusus sebagaimana tertera pada gambar 2.

Dari output Heteroscedasticity scatter plot, terlihat pancaran data tidak menunjukkan atau menggambarkan 
Analisis Strategi Bersaing UKM Batik.... (Isbandriyati Mutmainah, Irmawati \& Rumna)

sebuah pola tertentu, hal ini

menunjukkan bahwa model persamaan

yang melihat pengaruh variabel kualitas

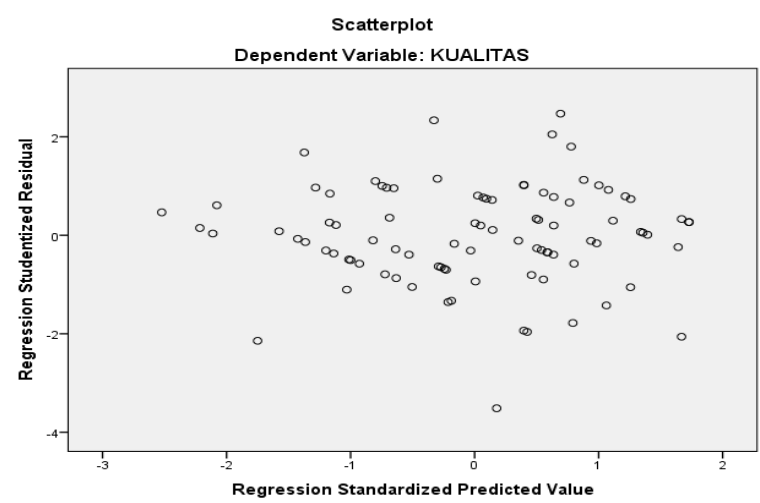

\section{Gambar 2. Heteroscedasticity Scatter Plot}

aset strategis, adaptabilitas lingkungan,

adaptabilitas teknologi informasi, dan

orientasi kewirausahaan terhadap

kualitas strategi bersaing tidak mengalami masalah heteroskedastisitas.

\section{4) Autokorelasi}

Salah satu asumsi dasar dari penerapan metode regresi dengan kuadrat terkecil adalah tidak adanya korelasi antar gangguan atau otokorelasi. Adanya masalah otokorelasi ini akan menghasilkan hasil estimasi koefisien yang konsisten dan tidak bias tetapi dengan varian yang besar, atau dengan perkataan lain hasil penafsiran tidak efisien. Varians estimasi parameter yang tidak efisien ini menyebabkan nilai $\mathrm{t}$

hitung cenderung kecil dan hasil
pengujian cenderung menerima
hipotesis nol $\left(\mathrm{H}_{0}\right)$.

Tabel 8. Tabel Hasil Uji Otokorelasi

\begin{tabular}{|l|c|c|c|c|c|}
\hline Model & $\mathbf{R}$ & $\begin{array}{c}\mathbf{R} \\
\text { Square }\end{array}$ & $\begin{array}{c}\text { Adjusted } \\
\mathbf{R} \\
\text { Square }\end{array}$ & $\begin{array}{c}\text { Std. } \\
\text { Error of } \\
\text { the } \\
\text { Estimate }\end{array}$ & $\begin{array}{c}\text { Durbin- } \\
\text { Watson }\end{array}$ \\
\hline 1 &, $714^{\text {a }}$ &, 510 &, 487 &, 43185 & $\mathbf{1 , 7 4 7}$ \\
\hline \multicolumn{2}{|l}{ a. Predictors: (Constant), KWH, TI, ASET, LINGK } \\
\hline \multicolumn{2}{|l}{ b. Dependent Variable: KUALITAS } \\
\hline
\end{tabular}

Dari hasil pengolahan data, nilai DW dari persamaan regresi yang dibangun dapat dilihat pada ringkasan Tabel 8 .

Dari tabel 8 dapat dijelaskan bahwa dengan nilai DW hitung sebesar 1,747 yang berarti ada pada kisaran nilai DW tabel antara -2 sampai 2, maka disimpulkan bahwa model regresi yang dibangun tidak terdapat autokorelasi.

\section{Uji Hipotesis}

Berdasarkan hasil pengolahan data dapat disajikan ringkasan persamaan regresi sebagai berikut:

KUALITAS $=$

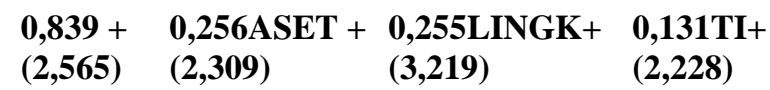

\section{$0,161 K W H+e_{i}$}

$(2,267)$

$\begin{array}{lll}R^{2} & = & 0,510 \\ \text { Adjusted } R^{2} & = & 0,487 \\ \text { F Hitung } & = & 22,145\end{array}$


Tabel 9. Ringkasan Persamaan Regresi

\begin{tabular}{|c|c|c|c|c|c|}
\hline Variabel & 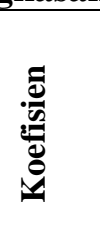 & 葛 & $\begin{array}{l}\bar{D} \\
\text { ड़ } \\
\end{array}$ & $\stackrel{500}{50}$ & 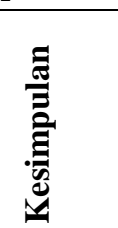 \\
\hline $\begin{array}{l}\text { Kualitas Aset } \\
\text { Strategis }\end{array}$ & 0,256 & 2,309 & 2,000 & & $\begin{array}{c}\text { Ho } \\
\text { ditolak }\end{array}$ \\
\hline $\begin{array}{l}\text { Adaptabilitas } \\
\text { Lingkungan }\end{array}$ & 0,255 & 3,219 & 2,000 & & $\begin{array}{c}\text { Ho } \\
\text { ditolak }\end{array}$ \\
\hline $\begin{array}{l}\text { Adaptabilitas } \\
\text { Teknologi } \\
\text { Informasi }\end{array}$ & 0,131 & 2,228 & 2,000 & & $\begin{array}{c}\text { Ho } \\
\text { ditolak }\end{array}$ \\
\hline $\begin{array}{l}\text { Orientasi } \\
\text { Kewitausahaan }\end{array}$ & 0,161 & 2,267 & 2,000 & & $\begin{array}{c}\text { Ho } \\
\text { ditolak }\end{array}$ \\
\hline
\end{tabular}

Tabel ringkasan persamaan regresi di atas menunjukkan pengaruh variabel-variabel bebas terhadap kualitas strategi bersaing. Koefisien-koefisien yang terdapat dalam bentuk ringkas memperlihatkan pengaruh dari variabel kualitas aset strategis, adaptabilitas lingkungan, adaptabilitas teknologi informasi dan orientasi kewirausahaan terhadap kualitas bersaing.

\section{Pembahasan}

Pengaruh variabel kualitas aset strategis terhadap kualitas strategi bersaing

Berdasarkan hasil pengujian hipotesis dapat dijelaskan bahwa variabel kualitas aset strategis berpengaruh secara signifikan terhadap kualitas strategi bersaing, dengan tingkat pengaruh sebesar 0,256. Hasil penelitian ini sejalan dengan hasil penelitian Kamener (2017), yang menyatakan bahwa untuk dapat bersaing pelaku usaha harus mempertimbangkan kualitas aset strategis, karena aset strategis berpengaruh terhadap kualitas strategi bersaing. Peningkatan kualitas aset strategis akan mendorong peningkatan kualitas strategi bersaing UKM batik Surakarta. Semakin baik kualitas aset strategis, semakin berkualitas strategi bersaing UKM Batik Surakarta. Aset strategis merupakan segala sumber daya yang dimiliki perusahaan yang menjadi kekuatan perusahaan untuk menghadapi kompetitor, yang dalam penelitian ini menggunakan tiga indikator yaitu kualitas aset strategis yang bersifat tangible, kualitas aset yang bersifat intangible, dan kualitas kapabilitas organisasi. Aset strategis yang bersifat tangible merupakan aset strategis yang dapat dilihat wujudnya, seperti nama merek dagang, sumber daya finasial, lokasi dan sebagainya. Pemberian merek dagang yang unik, sumber finansial yang kuat, pemilihan lokasi yang strategis misalnya dapat menjadi faktor pendorong peningkatan kualitas strategi bersaingnya. Upaya peningkatan kualitas aset tangible dapat dilakukan dengan memperbaiki 
atau merubah merek, memperbaiki fasilitas produksi, kemampuan untuk menguasai bahan baku, akses ke lembaga keuangan atau kerjasama, serta menetapkan lokasi yang strategis. Dalam hal pengaruh aset strategis yang intangible, semakin meningkat kualitas aset strategis yang intangible, semakin meningkat kualitas strategi bersaing. Perbaikan logo, peningkatan kompentensi sumber daya manusia, manajemen pengetahuan dan pengalaman perusahaan akan meningkatkan kemampuan pelaku UKM dalam menyusun strategi bersaing. Sedangkan peningkatan kapabilitas organisasi dilakukan dengan memperbaiki pelayanan, selalu berupaya mengembangkan produk dan meningkatkan koordinasi vertikal dan horizontal. Hasil ini mendukung penelitian dari Zabadi dan Mutmainah (2012) yang menyatakan bahwa bagi UKM, identitas produk adalah sangat penting bagi perusahaan dan berpengaruh secara siginifikan terhadap pemasaran produk.

Pengaruh variabel adaptabilitas lingkungan terhadap kualitas bersaing

Berdasarkan hasil pengujian hipotesis dapat dijelaskan bahwa variabel adaptabilitas lingkungan berpengaruh secara signifikan terhadap kualitas strategi bersaing, dengan tingkat pengaruh sebesar 0,255. Semakin adaptif UKM batik terhadap perubahan lingkungan maka kualitas strategi bersaing akan semakin meningkat pula. Hasil penelitian ini sejalan dengan penelitian Kamener (2017) yang menyatakan bahwa perusahaan harus mampu menyelaraskan kapabilitas perusahaan dengan lingkungannya. Sejalan juga dengan hasil penelitian Zulaikha dan Fredianto (2003) yang menyatakan bahwa perusahaan yang adaptif dan memiliki fleksibilitas yang tinggi dengan lingkungan eksternalnya memiliki kinerja yang lebih baik dibandingkan dengan perusahaan yang kurang adaptif dan memiliki fleksibilitas rendah. Upaya peningkatan adaptasi terhadap lingkungan dilakukan dengan cara memahami pelanggan, pemasok, penyalur dan pesaing. Bagi UKM batik, upaya memahami kebutuhan pelanggan dilakukan dengan senantiasa memperbaharui motif, model, bahan, harga dan selera pelanggan baik melalui riset maupun mengikuti perkembangan indikator-indikator tersebut. Upaya memahami pemasok dilakukan dengan menganalisis persediaan dari pemasok dan senantiasa mengestimasi kebutuhan perusahaan dalam periode tertentu dan estimasi kebutuhan yang 
akan datang. Menganalisis kebutuhan penyalur dilakukan dengan mempertimbangkan faktorfaktor yang berhubungan dengan loyalitas penyalur pada perusahaan, seperti harga dan pelayanan. Sedangkan analisis terhadap pesaing dilakukan dengan mengamati tren yang berkembang pada industri batik dan memutuskan langkah-langkah selanjutnya dalam menyikapi perubahan tren tersebut.

Pengaruh variabel adaptabilitas teknologi informasi terhadap kualitas bersaing

Berdasarkan hasil pengujian hipotesis dapat dijelaskan bahwa variabel adaptabilitas teknologi informasi berpengaruh secara signifikan terhadap kualitas strategi bersaing dengan tingkat pengaruh sebesar 0,131 . Semakin adaptif UKM batik terhadap perubahan dan kemajuan teknologi informasi akan semakin meningkatkan kualitas bersaing UKM batik Surakarta. Globalisasi menuntut pelaku UKM untuk mampu beradaptasi dengan kemajuan teknologi khusunya teknologi informasi. Kemajuan TI dapat dimanfaatkan untuk menjaring konsumen baru atau memperluas pasar ke wilayah yang baru. Adaptasi terhadap kemajuan TI juga mendukung kemampuan pelaku usaha untuk bertahan dan bersaing di pasar pada pasar yang semakin kompetitif, menjaga wilayah pasar yang ada dari upaya-upaya pesaing yang tidak sehat seperti duplikasi motif, model dan sebagainya.

Pengaruh variabel orientasi kewirausahaan terhadap kualitas bersaing

Berdasarkan hasil pengujian hipotesis dapat dijelaskan bahwa variabel orientasi kewirausahaan berpengaruh secara signifikan terhadap kualitas strategi bersaing, dengan tingkat pengaruh sebesar 0,161. Semakin bagus orientasi kewirausahaan, semakin meningkat kualitas bersiang UKM batik Surakarta. Hasil penelitian ini sejalan dengan hasil penelitian dari Alimudin (2015) yang menyatakan bahwa inovasi dan keberanian mengambil resiko yang merupakan karakteristik dari orientasi kewirausahaan berpengaruh terhadap keunggulan bersaing berkelanjutan. Demikian juga hasil penelitian Lee dan Peterson (2000) menyatakan bahwa perusahaan dengan orientasi kewirausahaan yang baik akan mampu meningkatkan kinerja. Peningkatan orientasi kewirausahaan dilakukan dengan meningkatan kemampuan perusahaan untuk berinovasi (innovatiness), meningkatkan keberanian dalam mengambil resiko (risk-taking), serta memanfaatkan setiap 
Analisis Strategi Bersaing UKM Batik.... (Isbandriyati Mutmainah, Irmawati \& Rumna)

peluang (proactiveness). Keberanian dalam mengambil resiko, bagi UKM batik dilakukan dengan memperluas pasar ke kosumenkonsumen potensial seperti remaja dan anak, memproduksi batik dengan motif-motif kontemporer yang keluar dari pakem. Memanfaatkan peluang dapat dilakukan dengan secara aktif mencari informasi berkaitan dengan batik dan produk-produk batiknya.

\section{KESIMPULAN DAN SARAN}

Kualitas strategi bersaing UKM batik Surakarta berada pada level berkualitas. Pelaku UKM batik Surakarta mampu bersaing dengan pelaku usaha sejenis baik dengan sesama pelaku usaha di wilayah yang sama maupun pelaku usaha dari wilayah lain yang memasarkan pada konsumen yang sama. Berkualitasnya strategi bersaing didukung dengan bernilainya produk yang dihasilkan, produk juga berada pada tingkat kelangkaan yang cukup tinggi, produknya cukup sulit ditiru dan pelaku usaha cukup mampu mengeksploitasi sumber daya yang dimiliki.

Variabel aset strategis, adaptabilitas lingkungan, adaptabilitas teknologi informasi, dan orientasi kewirausahaan berpengaruh positif dan signifikan terhadap kualitas strategi bersaing, baik secara bersama-sama maupun secara parsial, di mana variabel kualitas aset strategis memberi pengaruh yang paling besar terhadap kualitas strategi bersaing.

Dalam upaya meningkatkan kualitas strategi bersaing, UKM batik Surakarta perlu meningkatkan kualitas asset strategis baik yang tangible maupun intangible serta meningkatkan kapabilitas organisasi, melalui penguatan permodalan, perbaikan tata letak showroom, intensitas promosi dengan memanfaatkan kemajuan teknologi informasi, manajemen pengetahuan serta kapabilitas sumber daya manusia melalui Pendidikan dan pelatihan. 


\section{DAFTAR PUSTAKA}

Anshori, Yusak dan Kusrianto, Adi. 2011. Keeksotisan Batik Jawa Timur, Memahami Motif dan Keunikannya. PT Elek Media Komputindo, Jakarta.

Alarape AA. 2014. Developing the Entrepreneurial Orientation of Owner Managers of Small and Medium Enterprises in Nigeria. Ife Center for Psychological Studies Nigeria. 22(1):218-231. http://hdl.handle.net/10520/EJC150774

Alimudin, Arasy. 2015. Strategi Pengembangan Minat Wirausaha Melalui Proses Pembelajaran. eJurnal Manajemen Kinerja. E-ISSN: 2407-7305

Barney, J B. 1991. Firm Resources and Sustained Competitive Advantage. Journal of Management, 17(1): 99-120.

Barokah, Siti Nur. 2011. Analisis Faktor-Faktor yang Mempengaruhi Kualitas Strategi Bersaing pada UKM Batik di Kota Solo. Jurnal Administrasi dan Bisnis, Volume 12 Nomor 3, Oktober.

Bucktowar, R., Kocak, A., \& Padachi, K. 2015. Entrepreneurial Orientation, Market Orientation and Networking: Impact on Innovation and Firm Performance, Journal of Development Entrepreneurship, 20(4). https://doi.org/10.1142/S1084946715500247

Chavan, Meena. 2005. An appraisal of environmental management systems: A competitive advantage for small businesses. Management of Environmental Quality, Bradford. 16(51): 444

Cortina, J. M., 1993, What is Coeficien Alpha? An Examination of Theory and Aplications Journal of Appllied Psychologym Vol. 78, No. 1, P. 98-14.

Coyne, Heide,1985. Alliances in Industrial Purchasing: the Determinants of Joint Action in Buyer Supplier Relationship.

Darmansyah dan Soebagyo, Daryono. 2010. Stimulus Ekspor terhadap Kinerja PerusahaanPerusahaan Batik, Jurnal Ekonomi Pembangunan, Volume 11 Nomor 2. 
Analisis Strategi Bersaing UKM Batik.... (Isbandriyati Mutmainah, Irmawati \& Rumna)

Dean J.T., Robert L Brown and Charles E. Bamford. 1998. Between Trust and Control: Developing Confidence and Partner Cooperation in Alliances. Academy of Management Review, 5(1): 4964

Gibbons, Patrick T, et al., 2003, Adaptability and Performance Effects Of Business Level Strategies: An Empirical Test, Irish Marketing Review, Vol. 16.

, Kementerian Koperasi dan Usaha Kecil dan Menengah Republik Indonesia, 2018, Statistik Koperasi dan Usaha Kecil Menengah, Jakarta.

Kamener, Dahliana. 2017. Faktor-faktor yang Mempengaruhi Kualitas Strategi Bersaing Industri UKM Bordiran/Sulaman di Kota Padang. Journal of Economic Education, 5(1): 90-105

Kuncoro, M. 2012. Strategi Bagaimana Meraih Keunggulan Kompetitif, Penerbit Erlangga, Jakarta

Wibowo Kuntjoroadi, Nurul Safitri. 2009. Analisis Strategi Bersaing Dalam Persaingan Usaha Penerbangan Komersial. Jurnal Bisnis dan Birokrasi, Administrasi dan Organisasi, 16(1): 4552.

Lee, S.M. and Peterson, S.I. 2000. Culture, Entrepreneurial Orientation, and Global Competitiveness. Journal of World Business, 35(4): 401-416.

Lumpkin GT, Dess GG. 1996. Clarifying the Entrepreneurial Orientation Construct and Linking It to Performance. The Academy of Management Review. 21(1): 135-172.

Lumpkin GT, Dess G.G. 2001. Linking Two Dimensions of Entrepreneurial Orientation to Firm Performance: The Moderating Role of Environment and Industry Life Cycle. Journal of Business Venturing, 16: 429-451.

Malhotra Naresh K. 2009. Marketing Research: An Applied Orientation 4th ed. New Jersey. Pearson Education, Inc.

McGee, John dan Sammut-Bonnici, Tanya. 2014. Competitive Strategy. Wiley Encyclopedia of Management, edited by Professor Sir Cary L Cooper. Copyright (C) 2014 John Wiley \& Sons, Ltd. 
Miller, Danny dan Friesen, Peter H. 1982. Innovation in Conservative and Entrepreneurial Firm: Two Models of Strategic Momentum. Strategic Management Journal, 3 (1).

Miller, D. \& Friesen, P. H. 1983. Strategy-Making and Environment: The Third Link. Strategic Management Journal, 4(3): 221-235.

Mutmainah, Isbandriyati. 2010. Analisis Efektivitas Pemberdayaan UMKM di Kabupaten Bogor (Studi Kasus Program P3KUM). Penelitian Hibah Dosen Muda. Perpustakaan Universitas Nusa Bangsa

Mutmainah, Isbandriyati; Irmawati; Rumna. 2016. Industrial and Macro Impact toward Competitiveness of Batik Small Medium Entreprises in Surakarta. Prosiding SNaPP: Sosial, Ekonomi dan Humaniora, 6 (1).

Nwachukwu Chijioke, Chládková Helena, Žufan Pavel. 2017. The Relationship between Entrepreneurial Orientation, Entrepreneurial Competencies, Entrepreneurial Leadership, and Firm Performance: a Proposed Model. Business Trends. 7(1).

Panggabean, Riana. 2008. Dampak Pemberdayaan UMKM dan Koperasi Melalui Program P3KUM Bagi Anggota Koperasi (Studi Kasus di Kabupaten Brebes), Jurnal Infokop Volume 16.

Paramayoga, R. dan Anshori, M.Y. 2015. Perencanaan Kawasan Tujuan Wisata Batik Desa Tanjungbumi, Madura. Prosiding Seminar Nasional Manajemen Teknologi XXIII.

Platin, Nida dan Ergun, Hande Sinem. 2017. The Relationship between Entrepreneurial Orientation and Performance; Evidence from Turkish SMEs. Business and Management Studies, 3(2). doi:10.11114/bms.v3i2.2408

Porter, Michael E.1985. Competitive Advantage: Creating and Sustaining Superior Performance, Macmillan, New York.

Primasari, Dona; Mutmainah, Isbandriyati. (2011), Pengaruh Informasi Akuntansi terhadap Kinerja Manajerial dengan Tiga Variabel Moderating (Studi Empiris pada BPR di Kabupaten Bogor), Jurnal Reviu Akuntansi dan Keuangan, 1(2). 
Analisis Strategi Bersaing UKM Batik.... (Isbandriyati Mutmainah, Irmawati \& Rumna)

Purnama dan Setiawan.2003. Analisis Pengaruh Sumber-sumber Keunggulan Bersaing Bidang Pemasaran terhadap Kinerja Perusahaan Manufacture di Indonesia. Jurnal Bisnis.

Rupidara, Neil. 2008. Modal Intelektual dan Strategi Pengembangan Organisasi dan Sumber Daya Manusia. Paper disajikan pada Diskusi Modal Intelektual UKSW. Salatiga, 21 February 2008.

Sitepu, Masliana Bangun. 2005. Mengatasi Berbagai Tantangan dalam Era Globalisasi melalui Peningkatan Perilaku Kewiraswastaan. Jurnal Ilmu Administrasi dan Organisasi, Bisnis \& Birokrasi, 13(1).

Sugiyono. 2016, Metode Penelitian Bisnis, Alfabeta, Jakarta

Sulistyorini, Utami. 2013. Model Peningkatan Kinerja Produk Ekspor UKM Batik Surakarta Melalui Pembangunan Modal Sosial dan Daya Inovasi, Jurnal Aministrasi Bisnis, Volume 14 Nomor X Agustus.

Walter Achim, Auer Michael, Ritter Thomas. 2006. The Impact of Network Capabilities and Entrepreneurial Orientation on University Spin-off Performance. Journal of Business Venturing, 21: $541-567$.

Wennekers, Sander, Van Stel Andre', Thurik, Roy, dan Reynolds, Paul. 2005. Nascent Entrepreneurship and the Level of Economic Development. Small Business Economics, 24. DOI 10.1007/s11187-005-1994-8

Wiklund Johan, Shepherd Dean. 2003. Knowledge-based Resources, Entrepreneurial Orientation, and the Performance of Small and Medium-sized Businesses. Strategic Management Journal, 24(13): 1307-1314. doi: 10.1002/smj.360.

Winata, Felix Andhy dan Sugiarto, Miyasto, J. 2016. Pengaruh Kualitas Hubungan dan Kemampuan Adaptasi Terhadap Lingkungan yang Mempengaruhi Keunggulan Bersaing dan Implikasinya pada Kinerja Perusahaan (Studi pada PT. Aga Pratama). Jurnal Bisnis Strategi, Vol. 25 No. 1 Juli. 
Journal of Management Vol. 16, No. 2, $2019: 223-248$

Zabadi, Ahmad; Mutmainah, Isbandriyati. 2012, Persepsi Pengrajin terhadap Identitas Produk pada Industri Kerajinan Kayu Anggota Koperasi Mitra Meubel Bojong Indah Klender Jakarta Timur, Jurnal Infokop, 20.

Zhang, X., Ma, X., \& Wang, Y. 2012. Entrepreneurial orientation, social capital, and the internationalization of SMEs: Evidence from China. Thunderbird International Business Review, 54(2), 195-210.

Zulaikha, Fredianto, Ronie. 2003. Hubungan antara Lingkungan Eksternal, Orientasi Strategik dan Kinerja Perusahaan, Program Pascasarjana Universitas Diponegoro, Tidak dipublikasikan. 